\title{
Media Pembelajaran Job Safety Induction Untuk Siswa Baru SMK Negeri 2 Tasikmalaya Program Keahlian MesinBerbasis Multimedia
}

\author{
Deris Alfiansyah Kurnia ${ }^{\mathrm{a}, 1}$, Murinto ${ }^{\mathrm{a}, 2}$ \\ aProgram Studi Teknik Informatika Universitas Ahmad Dahlan Jl. Prof. Dr. Soepomo, Janturan, Yogyakarta 5516 \\ 11.alfiansyah.kurnia@gmail.com*; ${ }^{2}$ murintokusno@tif.uad.ac.id
}

\begin{abstract}
Abstrak
Induksi Keamanan pekerja (JobSafety Induction) adalah sebuah latihan tentang keselamatan dan kesehatan kerja yang diberikan kepada pekerja baru, atau kontraktor yang bekerja dilingkungan perusahaan. Tujuan dari induksi keamanan pekerja (JobSafety Induction) adalah untuk mengkomunikasikan bahaya - bahaya, keselamatan dan kesehatan kerja umum yang terdapat di perusahaan selama pekerjaan mereka, sehingga bisa sadar serta bisa melakukan tindakan pengendalian terhadap bahaya tersebut. Berdasarkan hasil penelitian tersebut, sekolah menengah kejuruan dalam hal ini SMK Negeri 2 Tasikmalaya program keahlian mesin juga dirasa perlu untuk menyampaikan materi Job Safety Induction kepada siswa baru sebagai pengenalan mengenai aspek - aspek keselamatan dan kesehatan kerja yang ada dan berlaku sebelum memasuki area bengkel mesin SMK Negeri 2 Tasikmalaya.

Media Pembelajaran interaktif merupakan media yang tepat untuk menyampaikan informasi tentang Job Safety Induction kepada siswa baru, supaya lebih menarik dan interaktif. Penelitian ini dilakukan Dengan menggunakanmetode pengembangan multimedia yang terdiri dari perancangan konsep, perancangan aplikasi, pengumpulan materi, pembuatan aplikasi, testing aplikasi yang dilakukan dengan dua cara yaitu Black Box Test, dan Alpha Test.

Hasil penelitian ini menghasilkan sebuah produk aplikasi media pembelajaran berbasis multimedia Job Safety Induction yang berisikan materi - materi keselamatan dan kesehatan kerja (K3) yang ditampilkan dengan menarik dan interaktif, dan evaluasi pembelajaran mengenai materi yang disampaikan untuk mengukur pemahaman siswa terhadap materi yang disampaikan. Dari pengujian yang dilakukan didapatkan hasil responden setuju bahwa aplikasi ini layak digunakan, menarik, mudah dipahami, dan dapat meningkatkan pemahaman siswa tentang keselamatan dan kesehatan kerja.
\end{abstract}

Kata Kunci: Job Safety Induction, K3, Media Pembelajaran interaktif

\section{Pendahuluan}

Pendidikan adalah salah satu kebutuhan yang sangat penting bagi setiap Individu, Masyarakat dan Negara. Dalam pendidikan terjadi proses pembelajaran antara guru dan siswa yang bertujuan untuk meningkatkan pengetahuan, keterampilan dan sikap siswa baik di kelas ataupun diluar kelas. Pada proses pembelajaran guru bukanlah satu - satunya sumber belajar bagi siswa walaupun guru mempunyai peranan, tugas dan fungsi yang sangat penting bagi pembelajaran siswa dikelas, sebagai contoh siswa di SMK Negeri 2 Tasikmalaya Jurusan Teknik Mesin bisa mempelajari pelajaran yang diajarkan di sekolah melalui buku - buku yang disediakan di perpustakaan, atau dengan mencari informasi melalui internet atau menonton video yang diunggah di internet.

Salah satu mata pelajaran yang diajarkan kepada siswa baru di SMK adalah mata pelajaran tentang Induksi Keselamatan Pekerja (Job Safety Induction) atau keselamatan dan kesehatan kerja sebagai pengetahuan dan wawasan bagi siswa, juga sebagai pelajaran yang mendasari siswa dalam melakukan praktik di bengkel maupun praktek kerja lapangan di perusahaan. 
Di Perusahaan Induksi Keselamatan pekerja (JobSafety Induction) adalah sebuah latihan tentang keselamatan dan kesehatan kerja yang diberikan kepada pekerja baru, atau kontraktor yang bekerja di lingkungan perusahaan. Tujuan dari induksi keselamatan pekerja (JobSafety Induction) adalah untuk mengkomunikasikan keapada pegawai baru tentang bahaya-bahaya, keselamatan dan kesehatan kerja umum yang terdapat di perusahaan selama pekerjaan mereka, sehingga bisa sadar serta bisa melakukan tindakan pengendalian terhadap bahaya tersebut.

Menurut penelitian dari Health and Safety Executive dan Institute For Work and Health, 8 dari 16 kecelakaan kerja yang menyebabkan kematian terjadi pada 10 hari pertama di tempat kerja, setengah dari mereka terjadi dihari pertama kerja, dan risiko keselamatan kerja cidera hilang waktu (lost time injury) ditemukan sangat tinggi pada bulan pertama pekerjaan. Jadi materi safety induction sangat penting untuk disampaikan kepada para pekerja baru, kontraktor baru atau tamu yang baru pertama kali masuk ke area perusahaan. Berdasarkan hasil penelitian tersebut, sekolah menengah kejuruan dalam hal ini SMK Negeri 2 Tasikmalaya program keahlian mesin juga sangat perlu untuk diberikan materi Job Safety Induction kepada siswa baru sebagai pengenalan mengenai aspek - aspek keselamatan dan kesehatan kerja yang ada dan berlaku sebelum memasuki area bengkel mesin SMK Negeri 2 Tasikmalaya.

Salah satu media penyampaian informasi dan pembelajaran yang sedang banyak dikembangkan adalah media pembelajaran interaktif, dengan media pembelajarn interaktif ini diharapkan siswa akan lebih tertarik belajar dan lebih memahami tentang materi yang disampaikan dalam hal ini materi tentang Induksi keselmatan pekerja (Job Safety Induction) atau keselamatan dan kesehatan kerja.

Berdasarkan hasil kuesioner awal yang diberikan kepada siswa SMK Negeri 2 Tasikmalaya program keahlian mesin kelas XI, 9 dari 10 responden tidak mengetahui tentang pengendalian keadaan darurat yang ada di bengkel mesin SMK Negeri 2 Tasikmalaya, 8 responden menyatakan diperlukan contoh - contoh yang lebih real seperti video, animasi, dan media pembelajaran tentang materi keselamatan dan kesehatan kerja atau Job Safety Induction, dan 9 dari 10 responden menyatakan perlu dibuatkan sebuah aplikasi media pembelajaran yang lebih interaktif tentang keselamatan dan kesehatan kerja atau Job Safety Induction. Kemudian berdasarkan observasi yang dilakukan di SMK Negeri 2 Tasikmalaya program keahlian Mesin, pembelajaran tentang Induksi Keamanan Pekerja (Job Safety Induction) atau Keselamatan dan Kesehatan Kerja masih menggunakan metode ceramah. Guru hanya menerangkan dan menggambarkan contoh Induksi Keselamatan Pekerja (Job Safety Induction) atau Keselamatan dan Kesehatan Kerja hanya dengan komunikasi secara lisan dan dari modul pelajaran saja sehingga penyampaian materi kurang optimal.

Berdasarkan hasil kuesioner awal yang diberikan kepada siswa SMK Negeri 2 Tasikmalaya program keahlian mesin kelas XI, 9 dari 10 responden tidak mengetahui tentang pengendalian keadaan darurat yang ada di bengkel mesin SMK Negeri 2 Tasikmalaya, 8 responden menyatakan diperlukan contoh - contoh yang lebih real seperti video, animasi, dan media pembelajaran tentang materi keselamatan dan kesehatan kerja atau Job Safety Induction, dan 9 dari 10 responden menyatakan perlu dibuatkan sebuah aplikasi media pembelajaran yang lebih interaktif tentang keselamatan dan kesehatan kerja atau Job Safety Induction. Kemudian berdasarkan observasi yang dilakukan di SMK Negeri 2 Tasikmalaya program keahlian Mesin, pembelajaran tentang Induksi Keamanan Pekerja (Job Safety Induction) atau Keselamatan dan Kesehatan Kerja masih menggunakan metode ceramah. Guru hanya menerangkan dan menggambarkan contoh Induksi Keselamatan Pekerja (Job Safety Induction) atau Keselamatan dan Kesehatan Kerja hanya dengan komunikasi secara lisan dan dari modul pelajaran saja sehingga penyampaian materi kurang optimal.

Mencermati hal tersebut penulis memberikan solusi untuk penyampaian materi Jobsafety induction di SMKN 2 Tasikmalaya berupa Aplikasi media pembelajaran Job Safety Induction untuk siswa baru SMK Negeri 2 Tasikmalaya program keahlian mesin berbasis multimedia interaktif dengan tujuan mempermudah dalam proses penyampaian materi induksi keamanan pekerja (Job Safety Induction) atau keselamatan dan kesehatan kerja tersebut kepada siswa baru 
sebelum memasuki area bengkel mesin SMK Negeri 2 Tasikmalaya. Jadi guru tidak lagi menyampaikan materi tentang Job Safety Induction atau keselamatan dan kesehatan kerja dengan cara ceramah, cukup dengan menyiapkan media pembelajaran Job Safety Induction di lab komputer kemudian siswa mempelajari materi yang ada di dalam aplikasi media pembelajaran Job Safety Induction dan melakukan evaluasi untuk mengukur pemahaman siswa tentang materi yang disampaikan sehingga sedangkan fungsi guru disini sebagai pendamping siswa dalam belajar.

\section{Landasan Teori}

\subsection{Job Safety Induction}

Induksi keamanan pekerja (Job Safety Induction) merupakan sesi pengenalan mengenai aspek K3LL. Ruang lingkup Job Safety Induction meliputi penjelasan tentang kebijakan mutu dan K3LL, Struktur Organisasi, Profil kegiatan \& Sarfas Operasi, Fasilitas K3LL, Ketentuan Masuk Lokasi Kerja, Prosedur Keadaan Darurat, Prosedur pelaporan kondisi atau perilaku tidak aman dan Nearmiss serta Tugas, Tanggung Jawab dan Potensi bahaya dalam pekerjaan [1].

Induksi keamana pekerja (JobSafety Induction) adalah sesi training pengenalan terhadap lingkungan kerja yang diberikan kepada karyawan ataupun kepada kontraktor dimana dalam training ini dibahas tentang hal-hal yang berhubungan dengan keselamatan, kesehatan kerja, dan lingkungan. Di beberapa perusahaan menyebutnya dengan HSEInduction atau HSE Orientation. Pada dasarnya intinya tetap sama yaitu memberikan training pengenalan. Materi induksi keamanan (JobSafety Induction) atau hal-hal yang dibahas mencakup kebijakan - kebijakan K3L di perusahaan, prosedur - prosedur K3 termasuk prosedur tanggap darurat, material dan bahan berbahaya dan beracun, aktifitasaktifitas yang ada di perusahaan serta bahaya dan resiko yang ada ditempat kerja, agar kita lebih berhati-hati dalam bekerja dan terhindar dari resiko kecelakaan [2].

\subsection{Multimedia}

Multimedia adalah media yang menggabungkan dua unsur atau lebih media yang terdiri dari teks, grafis, gambar, foto, audio, video dan animasi secara terintegrasi. Multimedia terbagi menjadi dua kategori, yaitu: multimedia linier dan multimedia interaktif [3].

\section{Metodelogi Penelitian}

\subsection{Subjek Peneltian}

Subjek dalam penelitian ini adalah TBBM Pertamina (Pesero) Tasikmalaya dan SMK Negeri 2 Tasikmalaya program keahlian teknik mesin yang akan dibuatkan sebuah applikasi media pembelajaran tentang Job Safety Induction atau Keselamatan dan Kesehatan Kerjayang materinya diambil dari TBBM Pertamina (PERSERO) mengenai Job Safety Induction yang diimplementasikan di bengkel mesin SMK Negeri 2 Tasikmalaya.

\subsection{Alat Penelitian}

Alat yang digunakan dalam penelitian untuk membuat program aplikasi ini meliputi perangkat keras (hardware) dan perangkat lunak (software) yaitu dengan menggunakan laptop dan kamera untuk membuat video, kemudian untuk perangkat lunak (software) yang digunakan adalah yang adobe flash cs 6 untuk membuat sebuah aplikasi multimedia, adobe illustrator cs 6 untuk mengedit gambar vector, adobe premiere CC dan adobe after effect cs 6 untuk mengedit video dan membuat animasi, dan adobe audition cs 6 untuk merekam narasi video dan merekam narasi di aplikasi media pembelajaran.

\subsection{Metode Pengumpulan Data}

Adapun metode pengumpulan data yang dilakukan dalam penelitian ini adalah sebagai berikut:

\section{Studi Pustaka}

Merupakan metode pengumpulan data yang dilakukan dengan mencari, membaca dan mengumpulkan dokumen-dokumen sebagai referensi seperti artikel, literatur-literatur tugas akhir, 
buku tentang K3LH dan Job Safety Induction sebagai referensi untuk pembuatan media pembelajaran berbasis multimedia.

\section{Wawancara}

Merupakan metode yang dilakukan dengan tanya jawab secara langsung kepada salah satu karyawan TBBM Pertamina (PERSERO) Tasikmalaya dan salah satu guru di SMK Negeri 2 Tasikmalaya. Metode ini dilakukan untuk memastikan bahwa data yang diperoleh tentang proses pelatihan dan pembelajaran Job Safety Induction benar benar sesuai dengan fakta yang ada.

\section{Observasi}

Merupakan metode pengamatan secara langsung terhadap cara pembelajaran Job Safety Induction di SMK Negeri 2 Tasikmalaya dan TBBM Pertamina (PERSERO) Tasikmalaya. Selain melakukan pengamatan juga melakukan pencatatan dokumen yang berkaitan dengan subjek penelitian secara cermat dan sistematis.

\subsection{Metode Pengembangan Multimedia}

Metodologi pengembangan sistem mengacu pada Metode Pengembangan Multimedia Versi Luther-Sutopo. Adapun rangkaian kegiatan yang dilakukan dalam pengembangan sistem ini berdasarkan metodologi tersebut diantaranya adalah [4]:

\section{Konsep (Concept)}

Tahap konsep yaitu menentukan tujuan, termasuk identifikasi audiens, macam aplikasi (presentasi, interaktif, dll), tujuan aplikasi (informasi, hiburan, pembelajaran).Identifikasi audiens dilakukan untuk melihat secara langsung keadaan SMK Negeri 2 Tasikmalaya dan TBBM Pertamina (PERSERO) Tasikmalaya. Media pembelajaran ini berisi materi Job Safety Induction yang berupa teks, gambar, animasi 2 Dimensi dan video, pelatihan keamanan dan keselamatan kerja, serta resiko-resiko yang mungkin terjadi di area bengkel sekolah yang ditampilkan dengan tampilan layout menarik. Tujuan pengembangan media ini adalah memberikan manfaat yang positif bagi siswa SMK Negeri 2 Tasikmalaya, karena dengan media pembelajaran tentang Job Safety Induction atau keselamatan kerjadi sekolah akan lebih inovatif dan pemahaman mengenai materi Job Safety Induction atau keselamatan dan kesehatan kerjaakan lebih mudah dan lebih interaktif.

\section{Perancangan (Design)}

Perancangan produk dilakukan melalui dua tahap, (1) membuat flowchart, dan (2) merancang storyboard. Flowchart dibuat untuk memudahkan pengembang mengatahui alur dan hubungan dari setiap interface.Setelah merancang flowchart, berikutnya disusun sebuah storyboard. Storyboard adalah serangkaian sketsa yang dibuat untuk menggambarkan suatu urutan (alur cerita) elemenelemen yang diusulkan untuk multimedia interaktif. Storyboard bermanfaat sebagai petunjuk atau pedoman dalam menuangkan substansi ke dalam suatu program. Dalam kata lain, storyboard dapat diartikan sebagai uraian yang berisikan tentang penjelasan dari masing-masing alur dalam flowchart.

\section{Pengumpulan Materi (Material Collecting)}

Kegiatan berupa pengumpulan bahan atau materi pelajaran yang diperlukan untuk pembuatan produk, seperti materi pokok, aspek pendukung seperti gambar, video, audio, dan clip-art image. Pengumpulan materi pokok dilakukan dengan menggunakan buku pembelajaran Job Safety Induction atau Keselamatan dan Kesehatan Kerja, dan memanfaatkan jurnal-jurnal tentang materi yang terkait, sedangkan pengumpulan gambar, video, dan audio diperoleh melalui pembuatan sendiri, arsip pribadi, ataupun men-download melalui internet.

\section{Pembuatan (Assembly)}

Setelah selesai dengan perancangan flowchart, penyusunan storyboard, dan pengumpulan bahan materi, baru kemudian dilanjutkan dengan tahap pembuatan. Seluruh materi dan aspek pendukung 
(teks, gambar, video, audio dan animasi) digabungkan dalam satu produk media pembelajaran yang utuh menggunakan program Adobe Flash CS6.

\section{Pengujian (Testing)}

Setelah pengimplementasian rancangan dibuat maka pengujian terhadap aplikasi yang dibuat dapat segera dimulai. Pengujian sistem sangat diperlukan untuk menentukan keberhasilan suatu sistem, dan melakukan perbaikan-perbaikan jika masih terjadi kesalahan. Pada penelitian tentang pembelajaran Job Safety Induction pengujian sistem dilakukan dengan dua cara yaitu :

\section{a. Black Box Test}

Pengujian dengan cara black box test adalah pengujian dari aplikasi media pembelajaran Job Safety Induction berbasis multimedia interaktif, tombol-tombol navigasi sudah dapat digunakan dengan baik, materi yang disajikan sudah benar dan tidak ada kesalahan. Pengujian ini dilakukan dosen atau para ahli.

\section{b. Alpha Test}

Pengujian dengan Alpha Test adalah pengujian sistem yang dilakukan user untuk menjalankan aplikasi tersebut dan memberikan kuesioner angket pertanyaan kepada user serta diminta untuk mencoba menjalankan aplikasi secara langsung. Setelah mencoba menjalankan aplikasi yang dibuat, user diminta untuk mengisi angket atau kuesioner untuk memberikan penilaian terhadap aplikasi yang dibuat.

\section{Distribusi (Distribution)}

Distribusi adalah tahap mempublikasikan/penyebarluasan produk hasil pengembangan.Sasaran pemakai produk adalah siswa baru SMK Negeri 2 Tasikmalaya program keahlian teknik mesin.

\section{Hasil dan Pembahasan}

\subsection{Analisis Kebutuhan}

Analisis kebutuhan sistem adalah analisis terhadap kebutuhan - kebutuhan untuk membangun sebuah sistem. Sistem yang akan di bangun dalam penelitian ini adalah aplikasi media pembelajaran Job Safety Induction. Pada tahap ini yang dilakukan adalah:

\section{Analisis User}

Kegiatan ini merupakan kegiatan analisis terhadap kebutuhan antara siswa dan guru dalam membangun sebuah sistem dalam hal ini adalah aplikasi media pembelajaran Job Safety Induction.

\section{Analisis Kebutuhan User}

Penyampaian materi pembelajaran adalah tujuan utama dari pembuatan aplikasi media pembelajaran multimedia, sehingga diperlukan spesifikasi kebutuhan pemakai pada umumnya. Terdapat beberapa hal yang harus diperhatikan dalam memenuhi kebutuhan user dianataranya adalah sebagai berikut:

a. Aplikasi ini mampu menyamapaikan materi sesuai dengan silabus yang ada di sekolah.

b. Aplikasi ini mempunyai elemen multimedia diantaranya adalah grafis, teks, audio, animasi, dan video. Hal ini dapat membuat aplikasi lebih menarik dan tidak membosankan.

c. Aplikasi dapat diterima dengan jelas oleh pengguna. Untuk memenuhi kebutuhan pengguna.

\section{Analisis Kebutuhan Sistem}

Analisis kebutuhan sistem ini meruapakan analisis kebutuhan - kebutuhan data yang diperlukan dalam perancangan sistem. Sistem yang dibangun dalam penelitian ini adalah aplikasi media 
pembelajran Job Safety Induction untuk siswa baru SMK Negeri 2 Tasikamalaya program keahlian mesin perkakas berbasis multimedia menggunakan adobe flash.

\subsection{Perancangan Sistem}

\section{Perancangan konsep}

Tahap konsep yaitu menentukan tujuan, termasuk identifikasi audiens, macam aplikasi (presentasi, interaktif, dll). Tujuan pengembangan aplikasi media pembelajaran ini adalah untuk mempermudah dalam proses pembelajaran siswa tentang Job Safety Induction atau keselamatan dan kesehatan kerja, kemudian untuk meningkatkan pemahaman siswa terhadap Job Safety Induction atau keselamatan dan kesehatan kerja yang ada di area bengkel SMK Negeri 2 Tasikmalaya, dan menambah kesadaran siswa untuk selalu berprilaku aman dalam bekerja di bengkel. Dalam pengembangan aplikasi ini melibatkan 5 elemen multimedia yaitu teks, gambar, animasi dua dimensi, audio dan video.

\section{Perancangan (Design)}

Perancangan pembuatan produk dilakukan melalui dua tahap yaitu perancangan Flowchart dan perancangan Storybord. Flowchart dibuat memudahkan dalam mengetahui dan alur dan hubungan setiap Interface, kemudian setelah perancangan Flowchart selanjutnya adalah perancangan Storyboard sebagai petunjuk atau pedoman dalam menuangkan substansi ke dalam suatu program.

\section{Pengumpulan Materi (Material Collecting)}

Materi yang diambil diambil dari buku-buku keselamatan kerja yang didapatkan dari guru SMK Negeri 2 Tasikmalaya dan modul-modul Job Safety Induction dari karyawan TBBM Pertamina (Persero) Tasikmalaya yang bekerja di bagian HSE (Healt Safety Environment), kemudian data berupa gambar diambil dari internet kemudan di animasikan supaya lebih menarik, kemudia data berupa video di buat sendiri dengan bantuan rekan rekan, yang melibatkan siswa dan guru-guru SMK Negeri 2 Tasikmalaya, data yang terkumpul dijadikan sebuah data yang sesuai dengan silabus SMK Negeri 2 Tasikmalaya yang berlaku.

\subsection{Implementasi Perangkat Lunak}

Hasil Perancangan aplikasi media pembelajaran Job Safety Induction berbasis multimedia dibangun dengan menggunakan Adobe Flash CS6 dengan Action Script 2.0. Implementasi dari aplikasi ini adalah sebagai berikut:

\section{Antarmuka Halaman Opening}

Halaman awal pertama kali aplikasi dijalankan adalah halaman opening, terdapat animasi kotak yang diangkat naik ke atas kemudian akan muncul teks perintah untuk menekan tombol kotak tersebut untuk masuk ke halaman selanjutnya seperti yang ditampilak pada Gambar 1.

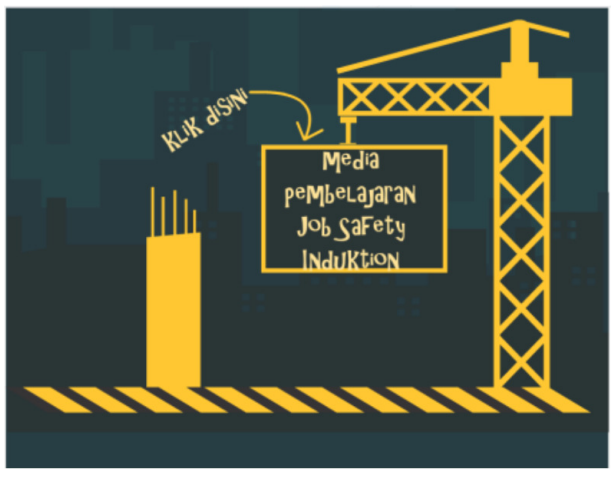

Gambar 1 Opening

2. Antarmuka Halaman Intro 
Halaman ini adalah halaman pembuka sebelum halaman utama. Terdapat animasi gear yang berputar kemudian pintu yang akan terbuka dan teks selamat datang sebagai pembuka aplikasi seperti yang ditampilkan pada Gambar 2.

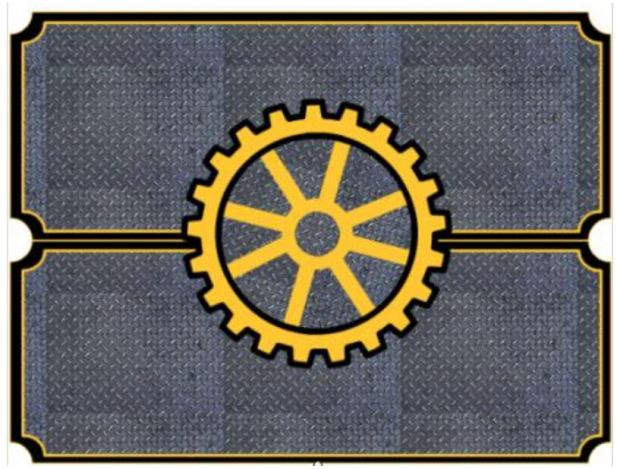

Gambar 2 Intro

\section{Antarmuka Halaman Utama}

Halaman ini adalah halaman utama dari aplikasi, terdapat beberapa menu diantaranya adalah Profile yang akan menunjukan profile pengembang aplikasi media pembelajaran Job Safety Induction, Menu Tujuan untuk menunjukan tujuan pembuatan aplikasi, Menu Materi berisikan tentang materi - materi Job Safety Induction atau Keselamatan kerja, terdapat 3 sub materi, materi 1 adalah materi mengenai pengertian keselamatan dan kesehatan kerja, dan rambu - rambu keselamatan dan kesehatan kerja, materi 2 berisikan tentang kegiatan yang ada di bengkel, alat alat perlindungan diri, dan table HIRA (Hazard Identification Risk Assesment), tabel HIRA adalah tabel yang mengidentifikasi bahaya-bahaya yang mungkin terjadi dan cara mengantisipasinya, kemudian materi 3 berisikan tentang video Job Safety Induction bengkel mesin SMK Negeri 2 Tasikmalaya, cara penanganan bahaya keadaan darurat gempa bumi, video General Safey Rules (Aturan Keselamatan Umum),dan video tentang cara menggunakan APAR (Alat Pemadam Api Ringan), Menu Evaluasi adalah menu yang berisikan soal - soal sebagai alat ukur pemahaman user atau siswa mengenai materi yang disajikan di menu Materi, Menu Tentang yang berisikan informasi tentang aplikasi ini, dan Menu keluar untuk keluar dari aplikasi ini, jika tombol keluar ditekan maka akan muncul pertanyaan verifikasi apakah user benar - benar ingin keluar dari aplikasi ini yang ditampilkan pada gambar 3 .

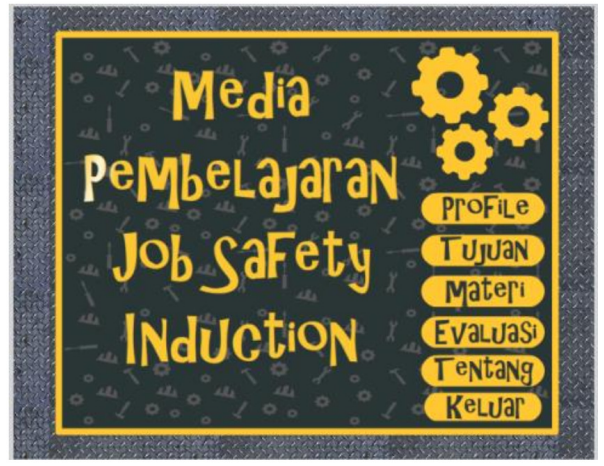

Gambar 3 Halaman Utama

\section{Antarmuka Halaman Profile}

Halama ini adalah halaman yang berisikan tentang informasi pembuat aplikasi, di halaman ini terdapat animasi logo Universitas Ahmad dahlan, backsound musik, dan tombol untuk kembali ke halaman utama yang ditampilkan pada Gambar 4. 


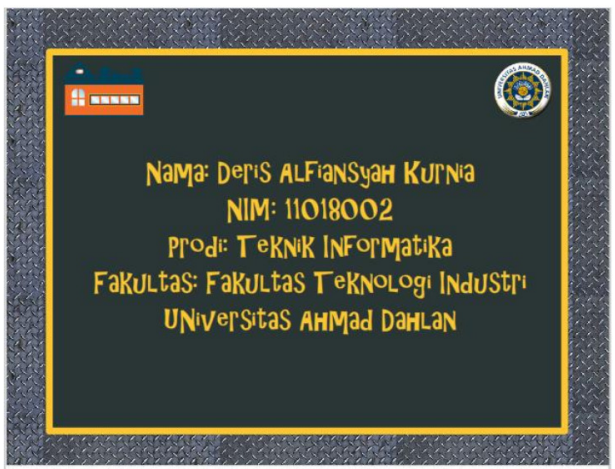

Gambar 4 Halaman Profile

5. Antarmuka Halaman Tujuan

Di halaman ini terdapat informasi tentang tujuan aplikasi ini di buat. Di halaman ini juga terdapat tombol untuk menuju halaman utama dan terdapat backsound musik.

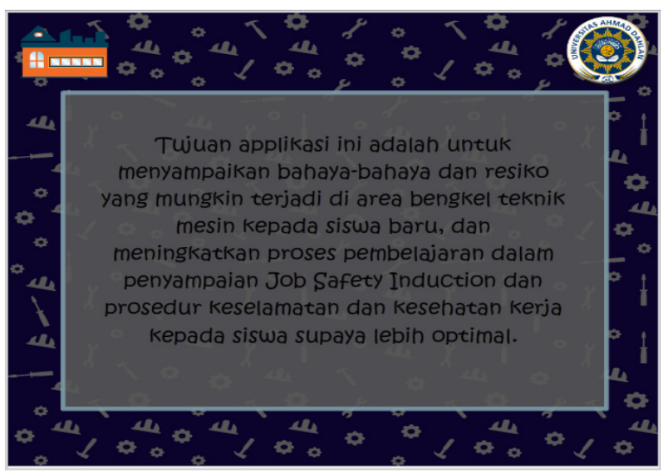

Gambar 5 Halaman Tujuan

\section{Antarmuka Halaman Materi}

Halaman ini adalah halaman yang berisikan tentang materi - materi keselamatan kerja atau Job Safety Induction, untuk pembelajaran siswa - siswa baru sebelum memasuki dan melakuakan kegiatan belajar di area bengkel mesin SMK Negeri 2 Tasikmalaya. Di dalam halaman ini terdapat kompetensi dasar dan tujuan pembelajaran, kemudian materi dibagi atas 3 Materi yaitu Materi 1 adalah Materi tentang definisi K3, UU K3, dan Rambu - Rambu K3, Materi 2 berisikan tentang kegiatan yang ada di bengkel mesin SMK Negeri 2 Tasikmalaya, Alat - alat Perlindungan Diri, dan Tabel HIRA (Hazard Identification Risk Assesment), Kemudian di Materi 3 terdapat Video Safety Induction SMK Negeri 2 Tasikamlaya, Video tentang Aturan Keselamatan Umum (General Safety Rules), cara menghadapi keadaan darurat gempa bumi dan Video tentang Cara menggunakan APAR (Alat Pemadam Api Ringan) seperti yang ditampilkan pada Gambar 6.

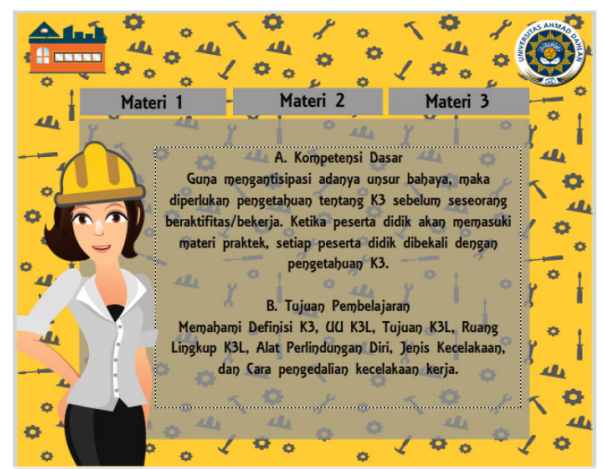

Gambar 6 Halaman Materi 


\section{Antarmuka Halaman Evaluasi}

Halaman Evaluasi adalah halaman yang berisikan mengenai soal - soal yang berkaitan dengan materi - materi yang disampaikan di menu "Materi". Terdapat 5 tipe soal yaitu Soal A, Soal B, Soal C, Soal D, dan Soal E, kemudian soalakan di random ketika user menekan tombol "Mulai" untuk kemdian mengerjakan soal. Pada saat mengerjakan memulai mengerjakan timer akan berjalan, jika timer sudah habis user tidak bisa lagi melanjutkan mengerjakan soal dan harus menekan tombol periksa untuk mengetahui nilai yang didapatkannya, jika nilai kurang dari standar atau 7 maka dinyatakan tidak lulus dan jika diatas standar atau diatas 7 maka dinyatakan lulus yang ditampilkan pada Gambar 7.

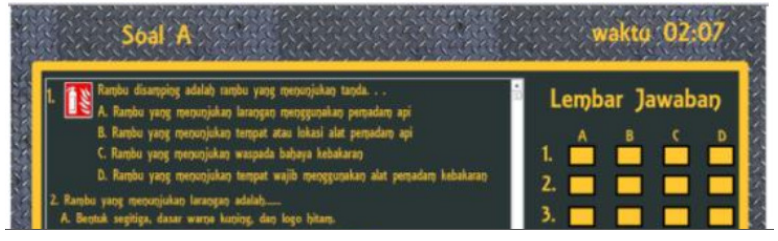

Gambar 7 Halaman Evaluasi

\section{Antarmuka Halaman Tentang}

Halaman ini adalah halaman yang berisikan mengenai informasi tentang aplikasi media pembelajaran Job Safety Induction, yaitu mengenai fitur - fitur didalam aplikasi, dan isi dari aplikasi yang ditampilkan pada gambar 9.

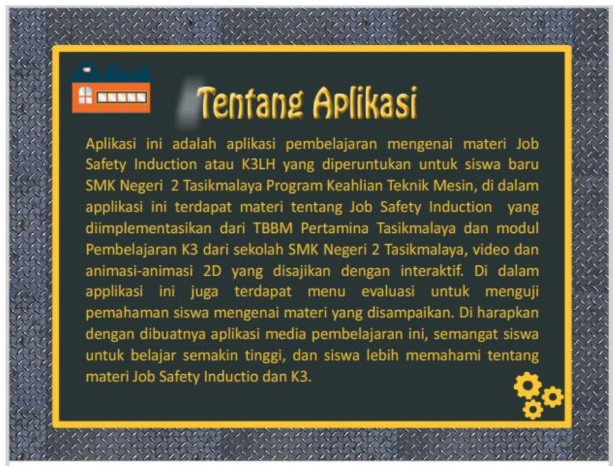

Gambar 8 Halaman Tentang Aplikasi

\subsection{Pengujian Sistem}

Pengujian sistem merupakan tahapan terakhir sebelum aplikasi atau sistem dipublikasidan didistribusikan. Tahapan pengujian dilakukan dengan dua cara yaitu pengujian Black Box Test dan Alpha Test. Hasil dari pengujian masing - masing adalah sebagai berikut:

\section{Black Box Test}

Pengujian dengan cara black box test adalah pengujian dari aplikasi media pembelajaran Job Safety Induction berbasis multimedia interaktif, tombol - tombol navigasi sudah dapat digunakan dengan baik, materi yang disajikan sudah benar dan tidak ada kesalahan. Pengujian ini dilakukan oleh guru SMK Negeri 2 Tasikmalaya dan karyawan TBBM Pertamina (Persero) bagian HSE. Jumlah responden sebanyak 2 (dua) orang dengan jumlah pertanyaan kepada responden sebanyak 22 (dua puluh dua) pertanyaan. Berdasarkan hasil pengujian yang telah dilakukan semua responden menjawab setuju untuk seluruh pertanyaan yang diberikan.

\section{Alpha Test}

Pengujian dengan Alpha Test adalah pengujian sistem yang dilakukan user untuk menjalankan aplikasi tersebut dan memberikan kuesioner angket pertanyaan kepada user serta diminta untuk mencoba menjalankan aplikasi secara langsung.Setelah mencoba menjalankan aplikasi yang dibuat, user diminta untuk mengisi angket atau kuesioner untuk memberikan penilaian terhadap aplikasi 
yang dibuat. Dalam pengujian ini user yang menguji adalah siswa SMK Negeri 2 Tasikmalaya Program keahlian Mesin Perkakas kelas X.

Jumlah responden adalah 20 (dua puluh) orang dan jumlah pertanyaan yang diberikan sebanyak 11 (sebelas) pertanyaan, jadi jumlah total skor adalah 220 (dua ratus dua puluh). Dari hasil pengujian tersebut diperoleh prosentase sebagai berikut:
1) Sangat Setuju (SS)
$: \frac{97}{220} \times 100 \%=44,09 \%$
2) Setuju (S)
$: \frac{100}{220} \times 100 \%=45,45 \%$
3) Kurang Setuju (KS)
$: \frac{23}{220} \times 100 \%=10,45 \%$
4) Tidak Setuju (TS)
$: \frac{0}{220} \times 100 \%=0 \%$

\section{Kesimpulan}

Dari uraian pembahasan yang telah disampaikan mengenai Media Pembelajaran Job Safety Induction untuk siwa baru SMK Negeri 2 Tasikmalaya secara umum dapat diambil kesimpulan:

1. Dari penelitian dihasilkan sebuah aplikasi Media Pembelajaran Job Safety Induction yang bertujuan sebagai pengenalan untuk siswa baru mengenai ketentuan umum, keselamatan dan kesehatan kerja serta pengendalian keadaan darurat yang berlaku di area bengkel Mesin SMK Negeri 2 Tasikmalaya.

2. Berdasarkan pengujian yang dilakukan yaitu pengujian Black Box Test dan Alpha Test diperoleh hasil yang positif, pengujian Black Box Test semua responden menjawab setuju untuk semua pertanyaan yang diberikan. Sedangkan pengujian dengan Alpha Test, responden menyetujui aplikasi ini menarik, mudah dipahami, dapat meningkatkan pemahaman mengenai keselamatan dan kesehatan kerja dan dapat membantu dalam proses pembelajaran mengenai keselamatan dan kesehatan kerja.

\section{Saran}

1. Materi yang disampaikan lebih diperluas lagi tidak hanya dititik beratkan kepada pengenalan ketentuan umum dan keselamatan dan kesehatan kerja yang ada dibengkel mesin saja.

2. Penambahan fitur - fitur seperti game edukasi akan lebih meningkatkan semangat siswa dalam belajar.

\section{Daftar Pustaka}

[1] Pertamina, Buku Panduan K3LL. Direktorat Pemasaran dan Niaga K3LL \& MM Pertamina, 2008.

[2] Agung Supriyadi, "Safety Induction : Mencegah Kecelakaan Kerja bagi Pendatang Baru Katigaku.top.” https://katigaku.top/2014/05/19/safety-induction-adalah/ (accessed Aug. 30, 2020).

[3] P. FLASH, W. WICAKSONO, and A. YOGYAKARTA, "PEMBUATAN CD INTERAKTIF PROSEDUR PENYELAMAN UNTUK."

[4] A. H. Sutopo, "Multimedia interaktif dengan flash," Yogyakarta Graha Ilmu, pp. 32-48, 2003. 